CHAPTER ONE

\title{
SOME HIDDEN STRENGTH
}

[S] tate power is rooted, in part, in the micropolitics of the localities.

(Boone 1998:25)

What holds Indonesia together? The question suddenly became urgent when widespread demonstrations amidst economic crisis forced the authoritarian President Suharto to step down in May 1998. Secessionist movements were active in Papua, Aceh and East Timor. When communal violence broke out in Maluku, Central Sulawesi and parts of Kalimantan, the word 'disintegration' suddenly leapt into the public discourse in Indonesia. For a while, no country in the world had more experts wondering aloud what the decisive national glue factor was. This dark question even began to overshadow hopeful ones concerning prospects for democracy and prosperity. Many thought society was so fractious that, without a strong figure at the top, the country would Balkanize, fall into religious fundamentalism, or descend into economic chaos. One foreign journalist wrote: 'Diplomats in Jakarta sometimes debate whether it is the breakup of the Soviet Union or of the former Yugoslavia that offers the better illustration of how things could fall apart in this country.' ${ }^{\prime}$ Similar fears had preoccupied foreign policy specialists in the mid-196os as the previous strong figure, Sukarno, grew frail. Both then and more recently, some with longer experience of the country spoke more optimistically about the strength of nationalism, the common language, and about the tolerance and pluralism that have always characterized these Southeast Asian people. In between the pessimists and optimists were those who simply felt Indonesia would somehow 'muddle on.'

There was cause enough for worry - Yugoslavia really did fall apart but on Indonesia the optimists turned out to be right. Other than having a sunny disposition, what did they know that others did not? It was my impression that they had traveled more. They experienced the nation not

1 Cameron W. Barr, 'No borders in Spice Island clash,' The Christian Science Monitor, 20 January 2000.

(c) Gerry van Klinken, 2014.

This is an open access chapter distributed under the terms of the Creative Commons Attribution-Noncommercial 3.0 Unported (CC-BY-NC 3.0) License. 
simply as an elaboration of an exemplary centre (a mandala, a powerful trope of Southeast Asian statecraft - Wolters 1999), but as a myriad of personalized networks spreading across the archipelago. Thus Jakarta's recurring crises were deprived of some of their power to spook them. It perhaps even translated to a different idea of the way power works across distance. Nobody formulated it quite like that, but it seems a productive possibility, and it is the jumping-off point for this book.

This is a book about the history of Indonesia viewed not from the top but from within those personalized networks that helped to establish national power. It presents the history of middle-class actors in one particular town in order to build an argument about the way power works in Indonesia more broadly. The remainder of this introductory chapter sets out some important preliminaries. The first of its five sections describes 'two Indonesias,' the extremities - a small heartland of money, government, and big cities, and a vast rural and provincial town periphery. The second introduces Middle Indonesia as a way to understand what holds those two Indonesias together, which is less elitist than a top-down approach. An adequate history of Indonesia requires a mental horizon that spreads, not simply from the 'centre' to the 'periphery, but from the commanding heights to that great middle that touches the bulk of ordinary Indonesians. The third and fourth sections turn to some theoretical literatures on power and class that underpin this broadened mental horizon. The fifth introduces one particular town, the object of the present study. It is located in a region of Indonesia that had so little contact with the Republic's formative experiences as to make the question 'what holds Indonesia together?' look very real. A chapter outline follows in the final section.

\section{Two Indonesias}

The common shorthand for regional differences within Indonesia contrast Java with the Outer Islands. Reality is a little more complex, but there is no question that a small number of heartland or core regions are easily distinguishable from a large peripheral zone. It is no exaggeration to speak of two Indonesias. While the heartlands are naturally prominent in the historiography - the personalities of national leaders (Friend 2003), the revolution in Java (Anderson 1972), the emergence of new forms of political community through 'print capitalism' (Anderson 1991) - a great deal of history-writing has been concerned with the problem of distance beyond the heartlands. Jean Gelman Taylor's marvelously accessible book 
Indonesia traces the slow growth of connections between widely separated peoples, particularly in the nineteenth century. 'Within the archipelago's many communities there developed an overlay of shared experience,' she wrote (Taylor 2003:238). New economic networks developed after 1800 when Batavia forced the outer islands to shift their trading links from Singapore to the new colonial capital. As the state and commerce expanded together, prosperity increased in Java and also in the peripheries - even if the benefits were not equally distributed (Dick et al 2002). In short, there is plenty of evidence to support the observation Ricklefs (2008:186) made in his standard history of Indonesia, when he wrote that 'the history of twentieth-century Indonesia was shaped to a considerable degree by this distinction [between Java and the outer islands].'

What distinguishes the heartlands from the periphery? Hugo et al $(1987: 84-8)$ quoted the following checklist of features of the heartland: a modern economy predominates (industry, services, or mining or plantations); commercial and transport networks from other regions have their focus here; foreign and domestic private investment plays an important role; the central government spends a lot of its foreign exchange and development funds in the heartland on modern infrastructure and from here carries out administrative functions that affect other parts of the country; and there are proportionately more large towns with social and cultural institutions (such as good universities) that also service other parts of the country. Most of Java has fallen into this category since colonial times, but so have the regions around Medan and (to a lesser extent) Makassar. Most of the money streams through these core areas, as well as a disproportionate amount of government activity. The largest cities are all in the heartland, with their associated flows of energy. In terms of connectivity - telegraph lines, steamship routes - Java was one of Southeast Asia's economic core areas, though always overshadowed by Singapore. The many evocative maps in the book by Dick and Rimmer (2003) on the globalizing impact on Southeast Asia of technological change, economic development and politics demonstrate how much of the archipelago's economic energy flowed through the core areas, particularly Java, and by contrast how little of it passed through the hinterland of the outer islands (e.g. pp. 28, 76, 85, 94-99, 220-1, 224).

The social tensions created by the rapid growth of capitalism were also greater in the core areas than in the peripheries, and this led to earlier and more intense social movements of all kinds there. Most of the turbulent twentieth century's mobilization took place in Java and parts of Sumatra. 
The sparsely-populated, poorly-connected and rural areas of the periphery, by contrast, saw little mobilizational activity. This can be easily learned by consulting Robert Cribb's Historical atlas of Indonesian history (2000, 2010). When the nationalist movement began in Java early in the twentieth century, the modern colonial state had put down deep roots in an island whose fertility had long provided the Netherlands with its colonial surplus. Adrian Vickers' history of modern Indonesia firmly locates that modernity in the cities (Vickers 2005:59-84). The colonial Dutch feared radicalism mainly in Java and parts of Sumatra (though South Kalimantan worried them too at times), and not without reason. The first mass movement Sarekat Islam (1912) and the Indonesian Communist Party (Partai Komunis Indonesia, PKI) (1920s) had their bases in Java. And the pattern continued after the Japanese interregnum. The economic importance of the heartlands led Java to become a battleground between republicans and the returning colonial Dutch after World War II. This is where the iconic revolution of national liberation largely played out. Communist party (PKI) votes in the 1955 election were concentrated in Java, as were votes for the populist Reformasi party PDI (Partai Demokrasi Indonesia) in $1999 .{ }^{2}$

However, the heartlands cover less than $15 \%$ of the territory's land area (even if Papua is excluded from the periphery, since it did not formally join the nation till 1969). In the outer island regions, an urban hierarchy of smaller towns reflects a shallower history of capitalist penetration and state formation. How did these peripheral areas of the archipelago become part of the nation? The work done on transport networks and on cities by the historical geographer Howard Dick $(1998,1986,2003)$ is relevant to this question about the political and social history of Indonesia. Dick recognized the steep contours between global city space, urban space and hinterlands, and the impact this had on the growth of the

2 Sarekat Islam, the first mass political movement in the Netherlands Indies, started in Surakarta, Java, in 1909. It won adherents throughout the colony, with some significant concentrations in southern Sumatra and eastern Borneo, but most were in Java (Cribb 2000:146). Later it split into a militant 'Red' communist movement and a moderate 'White' Islamic one. When in the late 1920 s the government began arresting communists for planning insurrection, most of the resulting convictions for political crimes occurred in Java (Cribb 2000:147). The self-proclaimed Republic of Indonesia in the late 1940s was confined to parts of Java and Sumatra, while its leadership was based in Java's Yogyakarta (Cribb 2000:160). Communist party (PKI) votes in the 1955 national election were strongest in Java, whereas conservative religious parties ruled the roost in the outer islands (Cribb 2000:163-5). Nearly half a century later, the opposition party PDI-P got most of its votes in 1999 in Java, whereas the regime party Golkar, a typical patronage party, continued to do well outside Java even after Suharto's departure (Cribb 2000:189-90). 
nation. Economic networks alone were not enough to tie the heartlands to the peripheries. The increasingly globalized elites in the big cities of the heartlands - previously colonial, now indigenous upper classes - did not and still do not care much about the poor periphery. Only the sheer territoriality of the state, with its national sovereignty respected by other states and its popular sovereignty exercised by citizens everywhere, saddles the national elite with a responsibility towards the rest. But they could not possibly live up to those responsibilities by themselves - they faced an 'action-at-a-distance' problem. Potential citizens were scattered over a huge area. The human diversity enclosed by the country's capacious boundaries is so extravagant that people can be forgiven for thinking of national unity as an accident of imperial history. ${ }^{3}$ How did national power bridge distances and reach into those areas where popular feelings had been lukewarm at best? To grasp that problem they, and we, need to travel into those vast spaces beyond the heartlands, where there is very little capital yet where millions of people live.

At first only a few privileged sites - places, people and their institutions - served as bridges across these distances. Over time, these pioneering sites of mediation facilitated increasingly dense new networks of communication. The towns functioned as nodes in these networks. Seen from beyond the heartlands, the puzzle of Indonesia's existence becomes a predominantly spatial one. How was an increasingly dense web of connections ultimately built between the heartlands and the peripheries? Central elites alone could not solve this problem. Middle class actors in provincial towns spread right across the country could, since they straddled the heartlands and peripheries socially and geographically. Pursuing these actors will result in a history of state formation from the middle rather than from above.

\section{Middle Indonesia}

The central premise of this book is that the terms on which Indonesia has survived from 1945 until the present day are co-determined in the regions,

3 Christine Drake (1989) plotted a number of integrative variables on a series of maps designed to indicate where the government needed to work harder at its 'assimilationist' strategies. They included integrative historical experiences such as revolution, shared socio-cultural characteristics such as language, religion and nation-wide organizations, transport and telecommunication, and economic interdependence. The maps show that eastern Indonesia was poorly integrated. Though such variables are too essentialist to be convincing, the maps remain suggestive. 
particularly in the provincial towns. Indonesia is a work in progress with an irreducible spatiality about it. The short-hand term 'centre-periphery' does not entirely do justice to this spatiality when it implies that the periphery is homogeneous. In reality those vast regions consist of smaller centres in which people think of themselves as 'central' in relation to their own 'periphery.' The network is a better metaphor - more on this below. Top-down or radial notions of power have not been good at grasping this networked spatiality. The country's urban hierarchy implies a spatial graininess, which separates places and people who are well-connected from those rural folk who, as Tania Li has put it, are increasingly 'surplus' (Li 2009). The better-connected towns are concentrated in the central island of Java, while the sparsely settled outer islands have far fewer sizeable towns and a less developed transport hierarchy. Researchers in the project of which this book is a part invented the name 'Middle Indonesia' for the social zone comprising middle classes in provincial towns. ${ }^{4}$ Middle Indonesia plays a primarily mediatory role, between the central state and the bulk of society.

Estimates of the number of spatially distinct, functionally urban areas in Indonesia vary widely. 'Functionally' urban means it does not just have a concentrated population but offers urban services such as banks and high schools. If we ignore the smallest towns, which are hardly functionally urban, a conservative number is 'about 200.5 About half the urban population lives in them. The economic and particularly the bureaucratic

${ }_{4}$ A description of this project, and of the term Middle Indonesia, can be read in the introductory chapter of Van Klinken and Berenschot 2014.

5 The following estimates have been made at various times (not a complete list).

831 - 'spatially distinct, functionally urban areas' - 1985 - the government's National Urban Development Strategy Project (NUDS 1985:65). Of these, 508 had populations over 10,000 . When neighbouring centres were agglomerated, this left 384 discrete urban centres over 10,000. Of these 85 had populations over $50,000-5^{2}$ of them in Java.

400 - 'definite towns' or 'towns in the narrow sense' - 1987 - from a German study in the 1980 s using direct field observations (not government data) and combining a 25,000 population threshold with a minimum number of 'central place facilities' such as banks, hospitals and schools (Rutz 1987:84).

270 - towns with populations in the range of 50,000 to a million - 2010 - http://www.citypopulation.de/Indonesia-CU.html\#Stadt_alpha (accessed 17 August 2013), using data from Axel Pieles; apparently based on government administrative boundaries, which means that (for example) suburbs of a large city such as Medan are reported as separate towns.

170 - towns with populations in the range 50,000 to a million - 2005 projection - calculated by myself from figures in Rutz (1987). One reason for the low estimate is that some entirely new towns have appeared since Rutz did his work, among them Batam (now nearly a million!). Other towns have changed their names (e.g. Ujung Pandang became Makassar). 
ties between the heartland and the peripheral areas all pass through the network of provincial towns that cover the entire country. The rapid spread of provincial towns in the periphery since late colonial times had everything to do with the establishment of a modern state in those regions (Rutz 1987:84).

The first social scientist to take a serious interest in Indonesian provincial towns was the Dutch sociologist W.F. Wertheim (1959) (but see also Logemann 1953). The towns that grew up throughout the overwhelmingly rural archipelago after the economic liberalization of 1870 and the final burst of pacification over the subsequent 40 years were western enclaves, he wrote. Europeans and Indo-Europeans dominated them despite their small numbers - less than $10 \%$ of the urban populations, fewer even than the ethnic Chinese inhabitants. The towns had a clear class structure, which was mirrored in their ethnic make-up. Moderately rich Europeans, often there only for a short-term posting, lived in beautiful open villas. Comparatively well-off middle class Indo-Europeans lived in good stone houses. Lower middle class Indonesians lived in 'decidedly bad' housing, especially in the large towns - perhaps a house in the 'better' kampong (which was still dirty), or else in very small and expensive new houses. The Chinese lower-middle class lived in overcrowded Chinese districts or in the kampong. The Indonesian poor lived in 'abominably bad' semi-rural kampongs - which were hovels and fire hazards. Town planners took no account of the poor majority, since Europeans thought Indonesians should live in a rustic traditional setting and not intrude into their town. The rising middle class, consisting of Indo-Europeans and Indonesian 'intellectuals,' were mostly officials. They maintained a nineteenth century 'mestizo' culture, while still emphasizing their own respective cultures. According to Wertheim (1959:185), these westernized urban Indonesians found themselves increasingly united across regional differences by 'cultural movements expressing social discontent.... [T]his new Indonesian culture was to be a typically urban culture. However small a percentage of Indonesians may have lived in the towns, these towns were the most dynamic element in Indonesian society, and thus assumed a very great influence on the social and political events throughout the archipelago.' 6

\footnotetext{
6 Wertheim (1987) was critical (in my view rightly) of a later study on the Indonesian town, edited by Nas (1986), for failing to understand that the town is 'an arena of social conflict.'
} 
Since then, the town's ethnic make-up has changed radically - most Europeans and Indo-Europeans are gone. But the political dynamism and the class differences - which were always the real key to the town's urban politics (Colombijn 2010) - have remained. Robert Van Niel (1960:22, 77) in his study on Indonesia's indigenous middle class also placed its origins in the early twentieth century in the towns, where a 'semi-Westernized element of great fluidity' - lesser aristocrats and even villagers with some western education - felt drawn to the European symbols of power and authority.

The city (kota) has been an important site in Indonesia's literary imagination. Indonesian novels set in the 1920s depicted the city as essentially a colonial construct, structured by the school and the government office (Kato 2003). The prestige of an official appointment exceeded that of the merchant's trade. But it was also a place of freedom. Love could blossom there, free from the social constraints of the village of origin. City people called themselves 'I' (saya), equivalent to the democratic Dutch first person singular $i k$, rather than the servile hamba or the inferior $a k u$. It was a place where western time was kept, punctuated by striking clocks and by a rest day on Sundays rather than at Friday prayers. Nevertheless, the middle-sized provincial town has remained almost invisible to the Indonesian reading public. Indonesian fiction appears to have no equivalent to Gogol's Dead souls or Updike's Rabbit series. Most of it is set in the iconic village or in the big city, but very little in the middle-sized provincial town. Even the observant Pramoedya Ananta Toer, whose early Tales from Blora are set in a provincial town, hardly seemed to notice the town as a spatial setting. This contrasts with India, for example, where small and intermediate urban centres are almost a field of research in their own right (Basile and Harriss-White 2003, Jeffrey 2010, Wessel 2001), and even has its own fiction (Mishra 2006). A new research focus on provincial towns in Indonesia is important not so much for the sake of the towns themselves but because they represent nodes of interaction in today's decentralized Indonesia. The premise underlying this book is that the 'micro-politics' (to use Catherine Boone's term) in and around provincial towns may not look very exciting, but they do continually help to constitute state power in this the world's fourth largest nation.

Unlike the term 'Middle America,' which suggests a somewhat static societal 'average,' in the middle of the bell curve, we intend the term 'Middle Indonesia' to convey the idea of a meeting place between extremes. As noted in the preface, the research proposal for the 'In Search of Middle Indonesia' project described it as a social zone that connects 
the metropolitan with the peripheral, along several dimensions. Along the spatial dimension, the provincial town occupies an intermediate position in the urban hierarchy, between village and metropolitan city. Along the socio-economic dimension, its middle classes are situated socially in between the very rich in their metropolitan gated communities and the urban and rural poor. Culturally, global fashions and localized practices meet in the provincial town on a more equal footing than in either the metropolis or the village. Economically, it serves as an entrepôt between an agricultural hinterland and national and global markets. Administratively, the town stands between the central state and local society - many towns are the seat of the lowest level of administrative autonomy (the district, kabupaten). Middle Indonesia thus occupies a halfway position along all four dimensions of the 'distance' separating the citizen from the state, in Diane Davis' (1999) helpful conceptualization. That distance is understood geographically, institutionally, and in terms of class and culture. The most excluded are those who live in small villages, have little access to institutions of power, do not belong to a class close to power, and do not share the culture of the powerful. Those in the middle are not only closer to the state than these people, but they can also mediate that closeness to them. Mediation is a social process, with both formal institutional and informal aspects. In politics as well as in the economy, the town displays a higher level of informality than does the metropolis - a high proportion of its workforce is informally employed; and politics are more personal and less institutional.

A brief historical sketch will illustrate both the problem and the crucial mediating role of Middle Indonesia in solving it. The Dutch considered most of the outer islands to hold little economic value. They had only pacified them late in the nineteenth century, mainly to keep out other imperial powers. They invested little in building a modern administrative machinery, instead leaving native authorities in charge. Cribb's historical atlas shows, for example, how much smaller the number of prisoners, military garrisons, and railway connections were in the colonial outer islands by comparison with Java (Cribb 2000:134, 136, 140). The periphery in most of eastern Indonesia, with its small towns scattered in an agrarian landscape, represents a different Indonesia to the one we normally encounter in the history textbooks. The distance that separated this other Indonesia from the heartlands of the state was certainly geographical, since the places that embodied it were physically remote from Java. But the region also had few people wealthy enough to have much influence in the heartlands, few institutions to connect with the new Indonesia, and 
moreover a culture (language, religion, lifestyle) that did not entirely recognize the world on the other side. The iconic national revolution of 1945-49, by which the nation would escape the accident of imperial history and assume its own identity, was in reality confined to merely a portion of the former Netherlands Indies, namely Java and parts of Sumatra (with considerable republican activity in South Sulawesi and parts of Kalimantan). These were the most populous parts of the archipelago, but covered only about $30 \%$ or so of its land area. The colonial Dutch resumed their rule over the remaining $70 \%$. Throughout the 195 os various regional revolts tore at the fabric of the nation; worst affected were Ambon, West Java, Sulawesi, and parts of Sumatra. Several were helped along by foreign powers. All were run by provincials out of the micro-politics of their towns. Desperate poverty turned the country into the basket case of Southeast Asia. The fact that Indonesia survived at all seemed a miracle. In most accounts, the instability of the 1950s was due to weakness at the centre, leading to numerous regional rebellions. And conversely its ultimate survival was attributed to successful centralization of power in Jakarta - Sukarno's charisma and the military's repressive reach. But this is both to overestimate Jakarta's autonomous strength and to underestimate the desire for national unity in the regions. Jakarta in those early years was itself divided between rival institutions, each of which looked for support in the regions. Sukarno had to travel constantly to maintain his influence. The armed forces were too fragmented to be truly effective even for internal policing, let alone to fight a unifying external war (which they tried against Malaysia and Dutch-held New Guinea with limited military success). Jakarta hardly dared to extract personal income taxes from its citizens for fear of non-compliance. Rather than lay down the law, it negotiated. Territorial integrity was its main worry. Provincial elites, keen to be part of the nation but proud of their own resourcefulness, were its most demanding negotiating partners. The chief instrument in Jakarta's arsenal was not the means of violence but patronage - mainly the gift of the means of primitive accumulation. The ideological mantle for these exchanges was a form of state socialism with broad emancipatory appeal, but whose statism found particular favour among a rising provincial middle class.

The big turnaround in this rather decentred polity came in late 1965 , when the fear of a communist takeover finally united the nation's fractious elites into supporting a centralized military counter-revolution (Slater 2011). The oil boom that fortuitously followed not much later boosted Jakarta's coffers. However, closer inspection reveals that even that 
centralizing regime change could only be established with support from the regions. Elites in the latter pledged their loyalty only in exchange for increased patronage. The threat of sabotage, which remained their chief weapon, operated behind closed doors throughout the New Order. It became audible to the public again as the New Order weakened in the early 1990s. In 1998 it led to an ambitious decentralization programme, which has 'structurally privileged cities' (Miller 2013). Nor had the provinces been merely divisive before 1965 . The unifying message of the republican revolution in the heartlands, the trade and transport networks established in the last decades of colonial rule, and the bureaucratic structures that replaced the rule of the rajas in the countryside, all passed through a network of provincial towns. So, whether for good or ill, for national unity or against it, the future of Indonesia has been co-determined in Middle Indonesia.

\section{Associational Power}

An alternative, less elitist notion of power has been mentioned repeatedly, but what does that actually involve? A book about this by the human geographer John Allen (2003) became for me an agenda-setting work. It opens with this striking rebuke: 'We have lost the sense in which geography makes a difference to the exercise of power.' Allen's book then offered two helpful insights. One was to deploy a notion of power that took into account the problem of transmission across space. Human proximity, face to face contact, is an essential element. The common instrumental idea of power is that of 'power over' others. It moves through bureaucracies as if it was a fluid. But proximity leads to a bottom-up idea of power, 'power to' get things done together. This has been called 'associational' power. Hannah Arendt wrote about it most cogently. She believed that only legitimate power was real. Power was about empowerment, about social capital that grows through collaboration. The Indonesian national revolution is a good example. By associating together in movements of solidarity, Indonesians generated enough power to defeat a well-armed, wellconnected western colonizer.

Allen's other key insight was that power operates in many different 'modalities.' The Indonesian revolutionaries expanded their solidarity by persuading others to join them. Sometimes they seduced them with dreams most people shared, at other times they enticed them with material rewards, or manipulated them with threats or impossible promises. Instrumental modalities of power operated alongside these associational 
ones. Propaganda was made, 'traitors' were imprisoned or murdered, dissidents intimidated. The revolutionary state had limited coercive capacities, however, and instrumental power was much less readily available than its leaders might have wished. Whether associational or instrumental, then, power is exercised in a wide range of modalities.

State institutions, when observed in this relational light, quickly lose the image of almost complete autonomy that their office-holders like to attribute to them, and that much scholarly analysis, particularly during the authoritarian New Order, allowed them to retain. Instead, they begin to look fragmented, contingent, and negotiated. Catherine Boone's comparative study on the history of state formation in three West African countries deployed the fertile phrase: 'state power is rooted, in part, in the micro-politics of the localities' (Boone 1998, 2003). In the period 1950-1970 these states built institutions out of the political constraints and opportunities that confronted them on the ground. Even though each West African state had the same problems - the one she examined was how to administer agricultural exports - they solved them in different ways because they met different forms of local resistance and collaboration. In those places where rural elites were in a position to challenge the state for a share of the profits, states built large and centralized bureaucracies (Ghana under Nkrumah); where rural elites were weak, states left a milder form of indirect rule (Senegal, Ivory Coast). In other words, African states are more deeply embedded in localized power relations than is generally assumed, and the same should be said for Indonesia. ${ }^{7}$

Rather than rigid structures in which power is immanent, a relational view of power suggests flows and mediation. Spatialized power is better understood in terms of network functions, notably brokerage. Consistent with Allen's mediated notion of power, I envisage associational power being created in the context of social networks. Indonesia's extensive geography created severe collective action problems. Michael Mann captured these problem precisely with his opening observation in his magnum opus on the nature of power: 'Societies are constituted of numerous

7 Other recent studies of state formation in Africa have similarly situated the development of large institutions in local configurations of power. They include Gillian Hart's study of a South African township (2002) and Jeffrey Herbst's sweeping history of African states (2000). They reflect the sense of path dependency, strategic interaction, and even irrational ritual that pervades the study of institutions in the various 'new institutionalisms' since the mid-199os (Hall and Taylor 1996). The present book moves in the same direction. We first developed these ideas in two introductory chapters for an earlier book on the socially embedded state in Indonesia (Van Klinken and Barker 2009). At the time we felt inspired by the 'state in society' ideas of Joel Migdal (2001). 
overlapping and intersecting sociospatial networks of power' (1993:I, 1). Technological means to mobilize resources at a distance did exist in the late 1940s - radio, newspapers, telephony, aeroplanes, ships and, ultimately, military force. These could help the centre project its will to the regions with minimal fear of distortion. But in this poor country ruined by war, such means were often too weak and the alternatives out there too numerous for organizational or electromechanical techniques alone to be decisive. Far more important were human brokers who were able personally to connect together geographically diverse social networks around the archipelago. The places of densest brokerage were the provincial towns. Mestika Zed's (1991) dissertation on the provincial brokers who ran Palembang is a pioneering exploration of this notion, which unfortunately remains unpublished.

Urban brokers of various kinds play important roles in this book. They included quasi-intellectual activists, military officers, bureaucratpoliticians, teachers, Chinese traders, and church leaders. Robert K. Merton, who pioneered the study of brokers, would have called the individuals in the present history 'cosmopolitan influentials' (1968:447). They had high status in and around Kupang. Their social capital derived from their ability to connect two places with widely different cultures, yet their social ties with the locals were in fact rather weak and asymmetric. They themselves were hardly any longer 'locals,' whose social capital grew out of organic embeddedness in the local community and who enjoyed strong symmetric relationships within their town community. At the same time, they possessed a local knowledge that the Dutch, the Japanese, and the Javanese could never achieve. In the more refined five-part typology of Gould and Fernandez (1989), they were 'liaison brokers,' mediators who stood outside both the groups they were trying to connect. ${ }^{8}$

\section{Intermediate Classes}

Since Wertheim described them as 'the most dynamic element in Indonesian society,' surprisingly few social scientists have focused specifically on

8 Brokers create a directed connection between two otherwise unconnected principal parties. Gould and Fernandez identified five types of brokers: 1 ) the coordinator (all three parties belong to the same group - internal brokerage); 2) the itinerant (broker from the outside, both principals belong to the same group - e.g. stockbroker); 3) the gatekeeper (broker belongs to the group being approached by a rival group - e.g. journal editor); 4) the representative (broker belongs to the group that is approaching a rival group - e.g. diplomat); 5) the liaison (broker comes from outside both rival groups - e.g. real estate agent). 
life in the urban settlements. Actually even the large cities have seen very little work - Abeyasekere's (1989) history of Jakarta and Dick's history of Surabaya (2002) being two notable exceptions. The first intensive work on towns was done by Clifford Geertz and his MIT associates. They picked a very small town in Java in the 1950s. They found it to be essentially static, a 'hollow town', reacting to outside stimuli in ways that were 'always defensive, reactive, evasive, and in the end .... sterile and debilitating' (C. Geertz 1965:5-7). The idea of stagnation was also strong in the work on provincial towns, such as that on Yogyakarta and Padang, by Hans Dieter Evers (1972). Later authors, however, began to see more dynamism and even conflict within the towns. Freek Colombijn's (1994) fine history of Padang found conflicts over urban space between 'strategic groups' that were in and others that were out of power. And Howard Dick, who picked the large city of Surabaya, found it to be riven by class conflicts over the urban land grabs that followed industrialization (Dick 2002:472). ${ }^{9}$ Class, absent from mainstream Indonesian studies for many years, may be making a come-back. ${ }^{10}$

Class analysis is often thought to be incompatible with the more horizontal brokerage analysis of the previous section. But brokers can have interests of their own. They can impress their interests on the action-at-adistance process by, as Marsden (1982) put it, charging 'commission.' Think of sabotage and rent-seeking. Indonesian provincial discourses of religion and ethnicity usually veil real material interests. Once provincial town politics became politicized in the 1930s, most of their actors were officials. That remains the case today. Burgeoning studies of Indonesian local politics in recent times have shown that they are capable of both modernization and exploitation. ${ }^{11}$ As the first optimistic flush of modernization theory was passing, studies of Third World 'urban bias' began exposing the ways in which narrow urban interests were able to hijack development plans intended for the nation as a whole (Bates 2008, Lipton 1977, Mellor 1976). A version of state socialism was popular all over the Third World in the early post-World War II years. Where this ideology

\footnotetext{
9 Some more examples are discussed in Chapter Two.

10 Official pressure on the social science research agenda in Indonesia must be part of the reason (Hadiz and Dhakidae 2005). Since the fall of the Berlin wall no one any longer claims that class is the primary dimension to social life. Race, gender and nationality are also important in various contexts. But class analysis does not depend on it being the main force at work.

${ }^{11}$ Some of the most relevant literature is conveniently summarized in the introductory chapters to Henk Schulte Nordholt and Van Klinken (2007) and Van Klinken and Barker (2009).
} 
placed state infrastructure development and industry above agrarian agendas it became a fig leaf for urban greed. Bates wrote of a core coalition consisting of government, industry, and organized labour - a coalition from which farmers were excluded and which resulted in deteriorating welfare for the poorest of the poor, the subsistence peasants.

A notable impulse to focus on these provincial urban coalitions, still worth reading, came from the Polish development economist Michal Kalecki (1972). Classes, whether big as in Marx or small as in much contemporary class analysis, are primarily a way of answering analytical questions about the connection between political action and material interests. Kalecki was particularly fascinated by the political action of a lower-middle class. His work on Indonesia and Egypt in the 195os led him to notice something few after him were to do, namely that the urban hijackers were not necessarily rich or at the top of the social pyramid. The politics of many underdeveloped countries were dominated by people from the lower-middle classes and rich peasants. This should be surprising because, whereas a ruling class normally serves the interests of big business, these members of the lower-middle classes did not. Kalecki's (1972:162) core thesis was as follows.

'Are there any specific conditions today favouring the emergence of governments representing the interests of the lower-middle-class (including in this also the corresponding strata of the peasantry)? It would seem that such conditions do arise at the present in many underdeveloped countries:

(i) At the time of achieving independence the lower-middle-class is very numerous while big business is predominantly foreign-controlled with a rather small participation by native capitalists.

(ii) Patterns of government activities are now widespread. Apart from the obvious case of socialist countries, state economic interventionism plays an important role in developed capitalist countries.

(iii) It is possible to obtain foreign capital also through credits granted by socialist countries.

In the process of political emancipation - especially if this is not accompanied by armed struggle - representatives of the lower-middle-class rise in a way naturally to power.'

Indonesia was one of the countries in which this unusual social inversion appeared to apply. Rather than working with big capital to develop the economy in a laissez faire fashion, the state wished to make the investments itself. The lower-middle classes were thus protected from foreign capital. Not only socialist countries practised economic planning but those in the western sphere of influence as well. The form of state 
capitalism that this produced, according to Kalecki, leads directly to the pattern of amalgamation of the interests of the lower-middle-class with state capitalism.' Where pure market capitalism was sure to force small firms out of business in its drive to industrialize, state interventionism would see them as essential for building up the country's productive capacity. This did not make them rich in absolute terms but did guarantee they would not fall back to the level of the peasant. Kalecki observed: 'It is true that this lower-middle-class and the prosperous peasants are not really rich; in many instances their standard of living is lower than that of workers in developed countries. But in comparison to the mass of poor peasants, who also flood the cities as unemployed or badly-paid home workers, the petty bourgeois is a tycoon with a lot to lose' (Kalecki 1972:166-7). The typical petty bourgeois fascination with religion and militarism, incidentally, is the reason why 'the governments in question favour religion - even to the point of adopting an official religion - and show a tendency towards external expansion and militarism associated with it.'

The politics of these provincial lower-middle class were motivated by a desire to maintain state protection against capitalist forces for themselves, and to keep class rivals at bay. Above them were the upper middle class, whose natural alliances were with foreign capital. In Indonesia these were the Dutch, and to some extent the Chinese, since indigenous capitalists could be counted on the fingers of one hand. Above them too was the native (largely bureaucratic) aristocracy. And below them were the numerous small landowners, landless peasants and urban poor, the latter mainly migrants from the countryside looking for work. White collar workers, meanwhile, were likely to be their allies, especially when employed by state enterprises. If Kalecki had gone a step further and mapped out his 'intermediate regime' argument in spatial terms, he might have added that the provincial town was the home territory for this surprisingly dominant lower-middle class. Several other social scientists, for example Cockcroft (1998) working in Mexico and Harriss-White (2003) in India, have made use of Kalecki's insights when writing about predatory urban coalitions that thrive in the middle regions of the social spectrum by means of their political rather than their entrepreneurial skills. HarrissWhite's work has been a particularly important inspiration for this book. Both are a sustained argument in support of Kalecki's observation, spatially extended.

Kalecki's intermediate class resembles Lenin's petty bourgeoisie, 'masters of the countryside,' but it does not fit neatly into the core Marxist 
two-class scheme of capitalists versus workers. It is neither clearly on the side of capital nor that of labour; its members have control over some means of production but they often also provide their own labour. It is not obvious who they are exploiting, if anyone. This led Harriss-White to use the term 'non-polar' for this class, an uncomfortable category on the margins of Marxist theory. Yet the reality on the ground is often exploitative, and there may be a better way of describing it. Instead of the now discredited labour theory of value, Aage Sørensen (200o) proposed rent-seeking as the source of inequality. Exploiters have access to assets that earn them rents, while the exploited do not. ${ }^{12}$ 'Assets' do not have to be money but can be many other things such as knowledge (education) or official power. In the bureaucratic politics that shaped Indonesia's provincial intermediate classes, the power to extract rents from government and to deny them to others are the fundamental driving forces separating the haves from the have-nots. The political turmoil that defines Middle Indonesia for us as observers revolves, to a large extent, about access to this asset.

It is the thesis of this book that middle classes in provincial towns are involved in some of the nation's most interesting 'action at a distance' processes. It is in this dynamic sense that Middle Indonesia is somehow constitutive of the country as a whole. That Indonesia did not fall apart after 1998 (except for the independence of tiny East Timor, annexed illegally in 1976) had as much to do with some hidden strength within Middle Indonesia as with leadership in Jakarta. The most interesting historical period to reconstruct, it seemed to me, lay between the 1930s and the 1980 . If ever there was a time when recurring crises confronted central authorities with 'action at a distance' problems it was in this period of economic decline, warfare, revolution, nation-building and authoritarian developmentalism. How were these problems addressed? To find the answer, I needed to go beyond the centre to the provincial towns in the periphery, which grew in this period from colonial backwaters to bustling entrepôts. I needed to examine the class-laden politics creating new social

12 Sørensen helpfully described three levels of 'theoretical ambition' among writers on class. One simply classifies the population nominally into strata according to certain criteria such as income or status. Another sees classes as observable, self-aware social groupings with identifiable boundaries (often based on occupation) and distinctive lifestyles and values. The highest level of ambition traces a fundamental antagonism between classes to structural economic inequalities between them. Exploitation, the key difference between Marxist and Weberian approaches, is a difficult concept, because the relationship between exploited and exploiter is always to some extent voluntary. However, many constraints on a perfect market have been identified, which all result in an unequal distribution of power over scarce resources. 
classes in the provinces as local governments penetrated indirectly ruled areas with modern techniques, and as provincial markets grew increasingly national. In these provincial processes I expected to learn about that hidden strength of Middle Indonesia.

\section{One Town}

This study explores the mediating roles between nation and countryside played by people belonging to the middle class of one run-of-the-mill town. This section introduces that town, and then places it in a broad historical, geographical and social context. Kupang lies on the Indonesian half of the island of Timor, which lies on the southeastern edge of the archipelago (Figure 1). On the tourist map (Figure 2, this grubby sheet seemed to be the last one available anywhere) the old heart of the town lies at the top left. The left bank at the mouth of the creek is the location for the Dutch fort Concordia, still standing and today a small military base. It was built by the Portuguese and taken over by a small Dutch VOC garrison early in the seventeenth century (Farram 2004, Fox 1977, Hägerdal 2012, Leirissa et al 1984). By the early nineteenth, the township was a significant imperial outpost. It became the capital of a new province in late 1958 , and began to expand rapidly in the 1970s. The old harbour now only takes small wooden boats and visiting sailing yachts - a new harbour was built at Tenau, $10 \mathrm{~km}$ to the west, in the mid-196os. But the Chinese godowns are still there on the other side of the creek, supplied by trucks from Tenau. From this old core, roads radiate towards newer parts of town. One runs east along the coastal flats, and eventually into the interior towards Timor Leste. Another runs southeast up the hill towards the governor's office and then the airport. A third passes the town's busiest traffic lights before heading even further up the hill south towards the university and education department offices.

Kupang has many unique peculiarities. Yet it too exhibits the 'inbetween' characteristics that Clifford Geertz, on the basis of his work in 'Modjokuto,' thought was so typical of the Indonesian provincial town $(1956,1963 \mathrm{c}, 1965)$. There were practical reasons for choosing this particular town. ${ }^{13}$ It was one of five towns within the broader Middle Indonesia

13 The original intention was to write a history based on more than one town. I was interested particularly in towns outside Java, because of their distance from Jakarta. But historical information about such towns proved so difficult to find for the crucial post-war period that one by one the other candidates dropped out, until only Kupang survived. In the $1960 s$, not a single provincial town outside Java had a newspaper that is archived today 

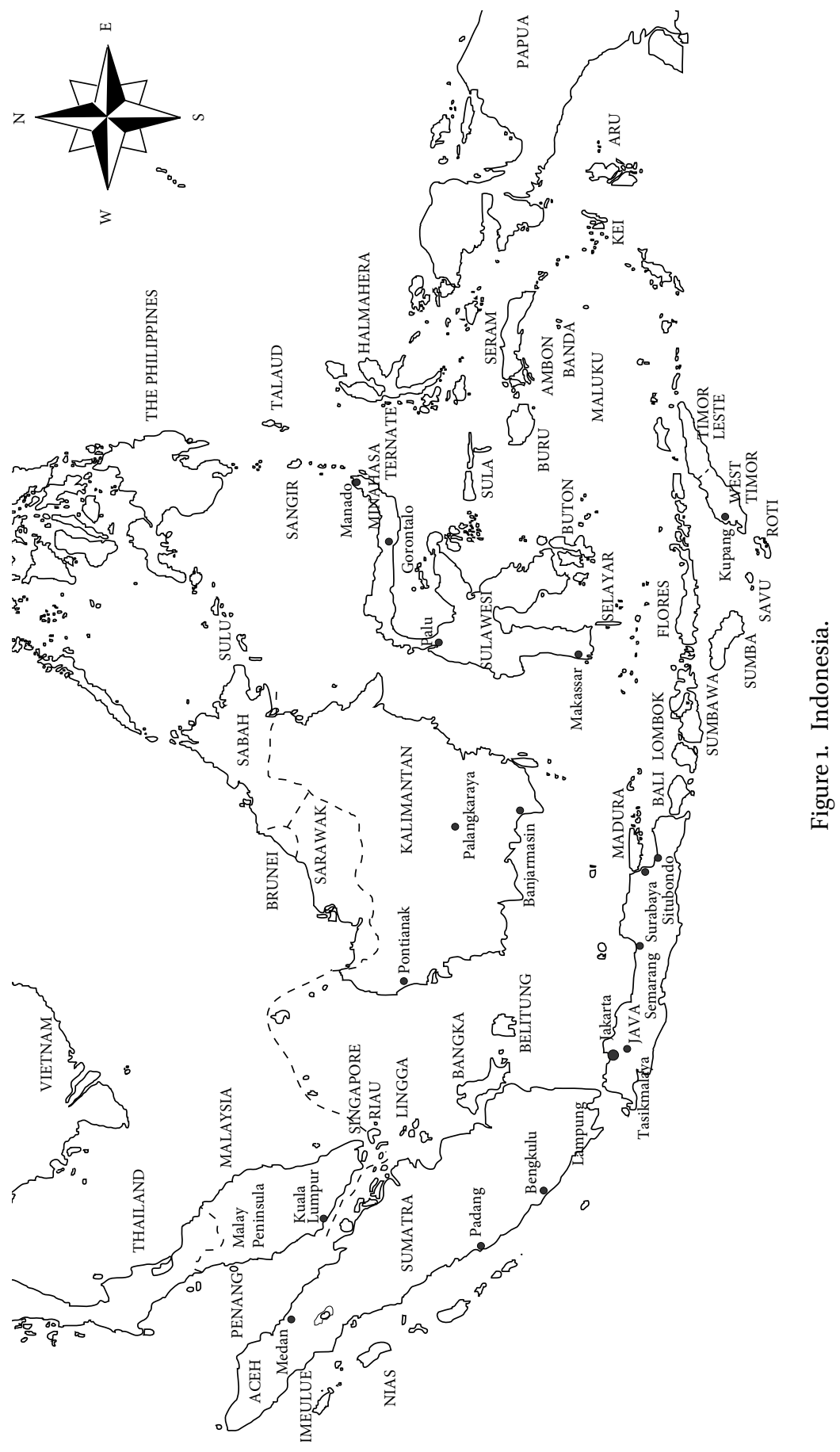


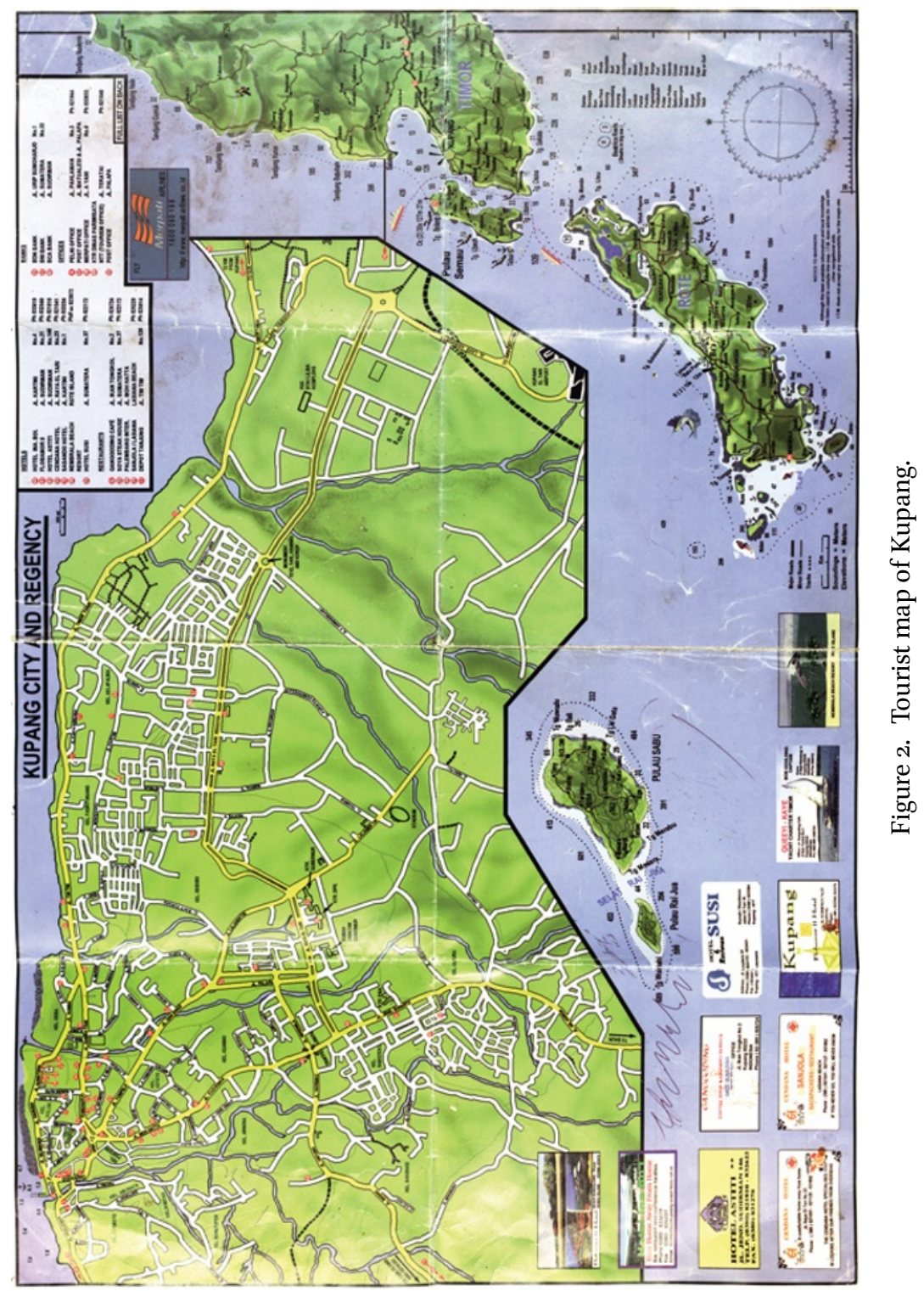


research programme for in-depth ethnographic work. Its economy was dominated by the state; others in the programme had more market-driven economies. A student in the Middle Indonesia programme, Sylvia Tidey, was writing an ethnographic dissertation on it (Tidey 2012), and one of our Indonesian colleagues wrote perceptively about his youth there in the 1970s (Lay 2014). The more one learns to know and love a town the less 'typical' it appears to be, and indeed there are clearly many distinctions to be made between towns (Nas 1981). But the intention, to restate it once again, has always been to look for generalizable processes of mediation along the several dimensions connecting the state with society that Diane Davis (1999) identified.

In 1930 Kupang had a population of 7,00o. By contrast, the leading city of Batavia at this time had 533,000 inhabitants, Makassar 85,000, and Ambon about 17,000 (Hugo et al 1987:101-2). Kupang was a colonial outpost in a poor subsistence economy. It lay at the end of the colonial shipping network whose main nodes were Makassar, Surabaya, Batavia, and then Singapore further west (Dick and Rimmer 2003:94, 96). All the small towns around the vast archipelago were run by a handful of Dutch officials, and had only a tiny indigenous elite interested in issues beyond the town. Most of these 7,000 were (descendants of) migrants from nearby islands. They lived in semi-rural wooden houses and talked about local affairs. In 2010 the town had a population of about 340,000 (BPS Kota Kupang 2011:47) - nearly 50 times larger. Its hinterland was and remains thinly populated and largely rural. We have no exact information on the town's evolving class structure. In general the increase of modern education throughout the twentieth century went hand-in-hand with urbanization. ${ }^{14}$ Even today Kupang still has no industry to speak of. The only

in the Indonesian National Library in Jakarta, and only Medan and Padang have substantial newspaper archives surviving from the 1950s (Hardjoprakoso 1977). These two cities are now too large to qualify as Middle Indonesian towns. Pontianak, a market-oriented town with a population today of half a million, gave up some of its secrets to me during several visits, but inter-ethnic suspicion made it difficult to dig deeper in the oral history; I hope to revisit this town in the future.

${ }_{14}$ Along with urbanization, literacy was extremely low everywhere in the colonial Netherlands Indies - under $20 \%$ for male adults (with a few exceptions) in 1920 , with female literacy far below that (Cribb 2000:38-41). Education participation rates for children were minimal - around 10\% as late as 1935 (Cribb 2000:144). Agriculture remained the main occupation in 1930, though at slightly lower levels in Java (55\%) than outside it (where it ranged up to $75 \%$, not counting plantations) (Departement van Economische Zaken 1936:33-5). All these indicators experienced steady development throughout the twentieth century, especially in the New Order after 1966. Urbanization and middle class formation went hand in hand with increased literacy. Today, the United Nations lists Indonesia as a 'middle income' country. Its middle class, based on generously low consumption 
exception is a large state-owned cement plant opened in 1980, but it was mothballed after going bankrupt in $2008 .^{15}$ Yet it has a substantial, confident middle class, culturally Indonesian and engaged in modern politics, which looks largely to the state for its income.

We set the lower bound of a typical Middle Indonesian town at 50,000. Many human geographers take this as the size beyond which a town becomes 'urban,' meaning it has grown beyond a small agricultural service centre and begins to host higher order services, such as government administration, education, health and commerce. ${ }^{16}$ The political scientist Robert Dahl (1967) once proffered that 50,00o may also be the minimal size for a town to host an effective urban civil society. Any smaller and its associational life was likely to dissolve into factional strife. In a postcolonial country, the town is more likely than the countryside to host the largely literate, non-agricultural, mobile, urban and reasonably prosperous society that, ever since Karl Deutsch (1961), is regarded as capable of generating modern institutional politics. That the sociality of cities is different - more competitive, more technological, more heterogeneous and above all more impersonal - has been a basic assertion since the inception of urban studies (Wirth 1938). But we still have little idea how politics in a postcolonial intermediate town differs from that in a large city or for that matter from that in a village. It is important to find out, because enormous numbers of people live in such towns. In between the small town and the metropolitan city of over a million, the intermediate town houses nearly a quarter of the country's population. Intermediate towns play mediating roles that reach perhaps $80 \%$ of the population. ${ }^{17}$ If these predictions about the varied social consequences of the population of a postcolonial town growing beyond the 50,000 threshold are correct then Middle Indonesia was made in Kupang somewhere in the halfcentury after 1930. By that last year the population had grown to 70,000, of whom the vast majority was literate. All other things being equal, this is

levels, has recently been estimated at $43 \%$ (ADB 2010). Literacy rates topped $80 \%$ by 1990 , urbanization rates reached $45 \%$ by 2004 , and more than half the working population said they worked mainly outside agriculture by the mid-199os.

15 'Berharap asap pabrik semen Kupang mengepul lagi,' Antara, 26 July 2009.

16 Rondinelli (1983:48-9) defines the secondary city in a developing country, which performs essential urban functions, as any centre over 100,000. Hardoy and Satterthwaite (1986:13-5) adopt a lower limit for the urban, defining the small town as 5,000-20,000, with the intermediate urban centre as 20,000-100,000.

17 Hardoy and Satterthwaite (1986:6) quote a UN figure showing that $80 \%$ of Third World populations generally live in or within the sphere of influence of intermediate towns. 
when it was able to sustain the dynamism of which Wertheim had written. Over this period we therefore expect to see some sort of urban civil society emerge - it is the making of Middle Indonesia that is of interest in this book.

Substantial towns are rare in Indonesia's periphery. Table 1 shows the distribution of towns counting at least 50,00o inhabitants throughout the archipelago between 1905 and 1980 . With only $7 \%$ of the total land area, Java's population density has given it a much higher density of substantial towns than the rest of the archipelago. The level of urbanization has always been similar in Java and the outer island, ${ }^{18}$ but substantial towns outside Java are widely scattered, leaving most people, particularly in eastern Indonesia, living in the vicinity of much smaller towns. In 1905 the Netherlands Indies was truly rural. Only four towns exceeded 50,000, and three of them were in Java. By 1930 the number had grown to just 17, of which 12 lay in Java, including the colonial capital Batavia. All the Javanese towns were moreover within such easy reach of each other by means of frequent trains, such that the distinction between village and city began to diminish (Dick and Rimmer 2003:133). Fifty years later, at the height of the developmentalist New Order, the human geographer Terry McGee

Table 1. Number of towns with populations exceeding 50,000 (Milone 1966:108-21, 129-53); 1980 column from Rutz (1987:265-82).

\begin{tabular}{llrrlrr}
\hline & 1905 & 1920 & 1930 & 1956 & 1961 & 1980 \\
\hline JAVA & 3 & 7 & 12 & 18 & 30 & 57 \\
OUTER & 1 & 2 & 5 & 11 & 19 & 55 \\
ISLANDS & & & & & & \\
Sumatra & 1 & 1 & 3 & No data & & 32 \\
Kalimantan & 0 & 0 & 1 & No data & & 6 \\
Sulawesi/ & 0 & 1 & 1 & No data & & 17 \\
Maluku/ & & & & & & \\
Bali/ Nusa & & & & & & \\
Tenggara & & & & & & \\
Kupang pop. & & 5,792 & 7,171 & No data & 29,831 & 91,633 \\
\hline
\end{tabular}

18 In the Netherlands Indies in 1930, 92.6\% of natives were rural in Java and 95.9\% in the outer islands (Departement van Economische Zaken 1936:2-6). The number of large towns per unit population is also the same: Java had $69 \%$ of the country's total population in 1930, and the same proportion of substantial towns. The population proportion has declined to $58 \%$ today, and with it Java's proportion of large towns. 
suggested that it was no longer analytically relevant to make the distinction, since villages had now become quasi-urban (creating a desakotavillage-city) (McGee 1991). The remaining five towns in 1930, meanwhile, were scattered over such a wide area of the far more poorly interconnected outer islands that, until today, no one has been tempted to abandon the distinction between village and city. In 1930, Kupang was not yet one of those significant towns. How it became one, and what role it played in the integration of Indonesia's heartlands with that other, more rural Indonesia in the periphery, is the burden of the chapters that follow.

\section{Chapter Outline}

The book opts for a conventional chronological chapter development, tracing the transition in Kupang from small colonial outpost in the 1930 s to the large town that it became in the mid-1970s. To capture the complexity of the themes discussed above, the approach mixes institutional and biographical narratives, at times approaching a social history (inasmuch as it is still possible to reconstruct it at this distance). Rather than simply recounting a story, however, each chapter aims to solve a problem. The historical arguments they attempt to build are best explained by outlining each subsequent chapter.

Chapter Two, 'A historical synthesis,' looks to history for an explanation for the politics of localism, ethnic identity, and bureaucratic careerism that typified Indonesian provincial town arenas after 1998. It is a synthetic, programmatic sketch of the intertwined histories of Indonesia's provincial towns, the central state, and the bureaucratic intermediate classes that dominate them. The networked dynamic of power gave provincial middle classes considerable room to manoeuvre. It turned them into assertive yet socially conservative political actors on the national stage, who at the same time uneasily manage their poorer citizens through webs of patronage.

Chapter Three, 'A researcher's notes,' focuses reflexively on the challenge of doing historical research in a provincial town in the global south. It is the first to zoom in on Kupang. The problems are severe, and help explain why Indonesian town histories are so rare. Paper archives are scarce. A greater obstacle is that a history of national political violence has created many taboos on local public discourse. The most interesting stories circulate only in private versions that 'must not be written.' The chapter also introduces some of Kupang's key mediating personalities, who will reappear in subsequent chapters. 
Chapter Four, 'Betting on the rajas,' explores the relations between the town and its hinterland. The problem of Middle Indonesia is not simply the conventional one of centre versus periphery. The town is itself a centre with a periphery. The intense struggles that took place in this regional arena in the 1950s and 196os were not simply re-enactments of national ones. They were the outcome of oppressive power relations that had crystalized in the countryside beyond Kupang in the 1930s. The Dutch were 'betting on the strong' when they invented a cheap system of indirect rule based on neo-traditional myths. Within the town, however, insulated from the rajas by 'the square mile' of Dutch sovereignty, a quiet town life, punctuated by rituals of church, sport and the harbour, was slowly taking in hints of distant worlds.

Chapter Five, 'Elite brokers,' examines the ways in which resource-rich agencies in cities far away - Makassar in Sulawesi, Singaraja in Bali, and Jakarta in Java - attempted to mobilize people in Kupang in the volatile period from 1934 to 1950 that spanned the Pacific War. Brokerage is the central mechanism. Most of the first local brokers were the sons of peasants who were educated as teachers and civil servants in Java before the Pacific War. At times of violent regime change, dictated far away - 1942, 1945, and 1949 - it fell to them to become the highly mobile interlocutors between the distant capital and their societies. This was a small town community, too small for any significant civil society. Starting out as the willing or unwilling tools of oppression in the hands of alien regimes, broker elites were to grow into an indigenous middle class with clear interests of their own.

Chapter Six, 'Authority,' examines struggles to establish new forms of authority within the Kupang region in the two decades after independence. Relations between the town and its countryside once more come to the fore. As the corps of people working for a government anxious to bring change grew between 1945 and 1973, and as the town as a whole grew with it, the problem of persuading country dwellers to accept the town's authority became increasingly acute. This chapter examines the communicative strategies regional elites deployed through two rather top-down institutions, the church and the military. Why was the relatively poorly resourced Protestant church so much more successful at this than the military? The answer is that associational power is more effective than centrally 'projected' instrumental power.

Chapter Seven, 'The seductress,' explores a communicative strategy that was by contrast quite successful. Political parties in and beyond the town in that innocent period following independence did generate 
associational power. Cross-class coalitions formed between middle class teachers and political party townsfolk, on the one hand, and rural peasants on the other. As the message of Indonesian republicanism began to resonate among a rural population exploited by the rajas, the store of social capital was enlarged, generating power to change things.

In Chapter Eight, 'The gatekeeper,' the contradictions that lay hidden in the various cross-class coalitions discussed in the previous two chapters begin to wreak themselves. Inequalities grew as senior brokers discovered they had the capacity to control the flow of resources passing through the town. The exploitative dynamics are illustrated by examining two small, local state-backed businesses. The communist party mobilized on the uneasiness this unfairness produced. Chapter Nine, 'The making of Middle Indonesia,' sees these incipient class tensions in and around the town erupt into full-scale violence, in step with the violence being deployed by central state institutions from late 1965 . Using a contentious politics analysis, it highlights the importance of local class tensions in what is usually seen only as a fight between the major players in Jakarta. The outcome was in many ways constitutive of Middle Indonesia as we know it today. Chapter Ten, 'A killing town,' tests the localist conclusions of the previous chapter by examining the ways in which the anticommunist pogroms were organized. Many local middle class actors were willing collaborators with the centrally coordinated military, driven by a mixture of national ideology and immediate material considerations.

Finally, Chapter Eleven, 'Consolidating Middle Indonesia,' examines the social strategies the winners of this local class conflict adopted to entrench their privileges. The conservative character of the town establishment has its origins as much in this local history as in the national political or economic regime or even the regional economy. At the same time, this chapter highlights the mutuality between Jakarta and these local establishments, which ensures that Indonesia holds together as a nation. A closing section in this chapter sums up what the book has learned about Middle Indonesia. 